\title{
Effect of base type on the dissolution of quartz with triisopropanolamine in minerals with silver occluded in quartz
}

\section{Efecto del tipo de base en la disolución del cuarzo con triisopropanolamina en minerales con plata ocluida en cuarzo}

\author{
SALAZAR-HERNÁNDEZ, Mercedes $\dagger^{* * 1}$, ELORZA-RODRÍGUEZ, Enrique ${ }^{1}, \quad$ SALAZAR- \\ HERNÁNDEZ, Carmen² and MENDOZA-MIRANDA, Juan Manuel ${ }^{2}$ \\ ${ }^{1}$ Universidad de Guanajuato, Department of Mining, Metallurgy and Geology Engineering; Ex Hacienda San Matías S/N, \\ colonia San Javier Guanajuato, Gto. CP 36000 \\ ${ }^{2}$ Unidad Profesional Interdisciplinaria de Ingeniería Campus Guanajuato. Instituto Politécnico Nacional, (UPIIG-IPN). Av. \\ Mineral de Valenciana No. 200 Col. Fracc. Industrial Puerto Interior, C.P. 36275, Silao de la Victoria, Guanajuato \\ México
}

ID $1^{\text {st }}$ Author: Mercedes, Salazar-Hernández / ORC ID: 0000-0001-8039-8124

ID $1^{\text {st }}$ Coauthor: Enrique, Elorza-Rodríguez / ORC ID: 0000-0003-4696-5898

ID $2^{\text {nd }}$ Coauthor: Carmen, Salazar-Hernández / ORC ID: 0000-0002-6901-2937

ID $3^{\text {rd }}$ Coauthor: Juan Manuel, Mendoza-Miranda / ORC ID: 0000-0003-4777-767X

DOI: 10.35429/EJT.2019.5.3.1.6

Received March 28, 2019; Accepted June 30, 2019

\begin{abstract}
The processing of refractory minerals of gold and / or silver occluded in quartz in sizes less than $1 \mu \mathrm{m}$ is not viable, due to the chemical inertness of the silica. The treatment of these minerals is usually carried out by reduction of particle size by fine grinding that allows the release of the occluded particles. As an alternative to processing these minerals, has proposed the partial dissolution of the silica with diols in basic medium; in these studies partial dissolution of the matrix has been observed in $25 \%$ with triisopropanolamine and $3 \% \mathrm{~mol}$ $\mathrm{KOH}$. The present work shows the effect of the type of base (organic-amines) in the dissolution of the matrix, observing a greater dissolution with the basic character of these and with the chelating effect of the same ones. $\mathrm{Et}_{3} \mathrm{~N}$ was the weak base that showed the highest dissolution of the matrix, observing a dissolution rate $\left(0.67 \mathrm{mmolmin}^{-1}\right)$ 2.5 times lower than that observed with $\mathrm{KOH}(1.66$ mmolmin ${ }^{-1}$ ), similarly the observed effective diffusion coefficient was of an order of magnitude lower than that observed with $\mathrm{KOH}$.
\end{abstract}

Dissolution, Type Base and Quartz

\begin{abstract}
Resumen
El procesamiento de minerales refractarios de oro y/o plata ocluida en cuarzo en tamaños inferiores a $1 \mu \mathrm{m}$, es poco viable, debido a la inercia química de la sílice. El tratamiento de estos minerales suele realizarse mediante reducción de tamaño de partícula mediante molienda fina que permita la liberación de las partículas ocluidas. Como una alternativa de procesamiento de estos minerales, se ha planteado la disolución parcial de la silice con dioles en medio básico; en estos estudios se ha observado la disolución parcial de la matriz en un $25 \%$ con triisopropanolamina y $\mathrm{KOH}$ al $3 \%$ en mol. El presente trabajo muestra el efecto del tipo de base (orgánicasaminas) en la disolución de la matriz, observándose una mayor disolución con el carácter básico de estas y con el efecto quelante de las mismas. $\mathrm{La}_{3} \mathrm{~N}$ fue la base débil que mayor disolución de la matriz mostró observando una velocidad de disolución (0.67 $\left.\mathrm{mmolmin}^{-1}\right) 2.5$ veces menor a la observada con la $\mathrm{KOH}\left(1.66 \mathrm{mmolmin}^{-1}\right)$, en forma similar el coeficiente de difusión efectivo observado fue de una orden de magnitud inferior al observado con la $\mathrm{KOH}$.
\end{abstract}

Disolución, Cuarzo, Tipo de Base

Citation: SALAZAR-HERNÁNDEZ, Mercedes, ELORZA-RODRÍGUEZ, Enrique, SALAZAR-HERNÁNDEZ, Carmen and MENDOZA-MIRANDA, Juan Manuel. Effect of base type on the dissolution of quartz with triisopropanolamine in minerals with silver occluded in quartz. ECORFAN Journal-Taiwan. 2019, 3-5: 1-6

\footnotetext{
* Correspondence to Author (email: merce@ugto.mx)

$\dagger$ Researcher contributing first author.
} 


\section{Introduction}

The main methods for the benefit-extraction of gold and silver from its minerals are flotation and cyanidation. In general, flotation schemes are used for the benefit of native gold, including stages such as: milling in the presence of a promoter (A-404, A-31), conditioning for 5 to 10 minutes with 50-300 g / ton of CuSO4, flotation at $35-40 \%$ solids by weight in the presence of $25-$ $50 \mathrm{~g} /$ ton of potassium amyl xanthate (XAP) and $60 \mathrm{~g} /$ ton of foaming agent.

The CuSO4 used during free gold flotation can increase the recovery of the metal, reactivating those particles that are tarnished or stabilizing the foam so that the gold carried between the interstices of bubbles is not lost when they emerge to the liquid interface -air. The presence of silver during the flotation of gold exerts a positive effect, as suggested by Deveter et al. in his flotation experiments with silver-gold plates [1]; likewise, the morphology of free gold can affect its ability to fix itself to air bubbles, which generally presents itself as plates with a large number of ridges and valleys $[2,3]$.

It is important to point out that the benefit of these ores by simple flotation processes can only be realized in the event that the metal is present free or as a secondary association, and given the fact that currently most of the gold present in the various The world's ores are in the form of complex associations with carbonated minerals, copper oxides and sulphides, this process is not viable or of low yield.

The second and most used process in Mexico and most of the world for the extraction of gold and silver from its ores; It is the so-called cyanidation process, which according to Habashi, the viability of the dissolution of gold and silver by cyanide was first demonstrated by Forrest and MacArthur [4,5]. This process is relatively simple and economical, it consists only of placing the ore in contact with a basic solution of $\mathrm{NaCN}$ for a certain time (up to $72 \mathrm{~h}$ ) in the presence of $\mathrm{O} 2$, which can come from a simple aeration system. The dissolution of the metal can be expressed according to Reaction 1.

$2 \mathrm{Au}+4 \mathrm{CN}^{-}+1 / 2 \mathrm{O}_{2}+\mathrm{H}_{2} \mathrm{O} \longrightarrow 2\left[\mathrm{Au}(\mathrm{CN})_{2}\right]^{-}+2 \mathrm{OH}^{-}$

(Reaction 1)
The mechanism of this reaction is of an electrochemical nature in which oxygen is reduced to hydroxyl ions and hydrogen peroxide, while gold oxidizes and complexes with the cyanide ions of the system. The reactions involved in this system are shown in Reactions 2-5 [5].

Anodic Reactions of the Cyanuration Process:

$$
\begin{aligned}
& \mathrm{Au}^{\circ} \rightarrow \mathrm{Au}^{+}+\mathrm{e}^{-} \\
& \mathrm{Au}^{+}+2 \mathrm{CN}^{-} \rightarrow \mathrm{Au}(\mathrm{CN})_{2}^{-}
\end{aligned}
$$

(Reaction 3)

Cathodic Reactions of the Cyanidation Process:

$$
\begin{aligned}
& \mathrm{O}_{2}+2 \mathrm{e}^{-} \rightarrow 2 \mathrm{O}^{=} \\
& \mathrm{O}^{=}+\mathrm{H}_{2} \mathrm{O} \rightarrow 2 \mathrm{OH}^{-}
\end{aligned}
$$

(Reaction 5)

In addition to the reactions of interest, a large number of side reactions also occur which basically cause the loss of cyanide (cyanicides). Species such as the sulfide ion, antimony and arsenic retard the dissolution of precious metals [6]. On the other hand, salts of metals such as lead and thallium in concentrations of $10 \mathrm{mg} / \mathrm{L}$, increase the dissolution rate of gold [7].

As can be seen, the cyanidation process is highly dependent on impurities and operating conditions. According to Habashi, the mechanism that controls the dissolution rate is diffusion through the boundary layer, and therefore dependent on the concentration of oxygen and cyanide in the solution [5]. In general, this process is comparatively simple and applicable to many ores that contain gold and silver; however, the speed of dissolution of the process is relatively slow, requiring residence times of up to 96 hours for some ore. Effective cyanidation depends on maintaining and achieving conditions such as: adequate release, sufficiently high cyanide and oxygen concentrations, and a high $\mathrm{pH}$ alkaline medium that prevents the hydrolysis and decomposition of cyanide by the effect of CO2 and / or the presence of acid matrices.

However, this process is inefficient for the benefit of the so-called "gold and / or encapsulated silver". In these cases, gold is generally occluded in sulphide or quartz matrices in sizes of the order of 2 to $5 \mu \mathrm{m}$. 
The release of this metal forces grinding processes to sizes equal to or less than that mentioned, this process being unprofitable, so these minerals cannot be economically benefited by conventional processes, either cyanidation or flotation.

As already indicated, a grinding process at sizes below 25 microns leads to inexpensive processes, which is why the search for physical or chemical pre-treatments that fracture or propitiate the dissolution of the silica matrix, which favors the ore benefit. Within the chemistry and technology of silicon, the feasibility of obtaining discrete silicon compounds from silica and various polyols, such as ethylene glycol [8-10], diethylene glycol $[11,12]$, N-phenyldiethanolamine have been studied [12,13], isoporpanolamine [14], triethanolamine [15], diethanolamine, in these works the dissolution of the silica is shown and as a possible mechanism of dissolution the breaking of the silica network, via the formation of hyper-intermediates of the diol in the network that favors the breaking of the Si-O-Si link in the network, for the formation of the silicon-diol complex [8-10,12].

These types of reactions have been evaluated in minerals with silver occluded in quartz, observing a dissolution of the matrix in $25 \%$ with triisopropanolamine at $220^{\circ} \mathrm{C}$ in basic medium [16] and partial de-occlusion of silver in sizes greater than $100 \mathrm{~nm}$ The present work shows the evaluation of the effect of the type of base in the dissolution of the matrix of the cyanidation tails of the mineral of the Minor District of Pinos Altos in Chihuahua with silver occluded in quartz of $2 \mu \mathrm{m}$ in size and with a law of $56 \mathrm{gTon}^{-1}$.

\section{Methodology}

\section{Mineral Characterization of the Mineral}

In this study, a sample of the cyanidation tails of a mineral from the Pinos Altos Mining District, Chihuahua, was used. Mineralogical characterization of the mineral was carried out by X-ray diffraction in a RIGAKU ULTIMA IV model diffractometer. The characterization by elementary scanning electron microscopy (MEB-EDS) was performed in a JOEL JSM6610LV microscope. The samples were coated with carbon in a SPI-Module-Carbon Coater, previously cleaned under high vacuum at 10-1 Torr.
The chemical characterization of the mineral was carried out by means of X-ray fluorescence spectrometry by dispersion of Cartesian geometry in a Rigaku NEX CG model $\mathrm{X}$-ray fluorescence spectrometer. The limit of detection and quantification of this technique for the studied elements is shown in Table 1.

\section{Ore treatment with triisopropanolamine}

Partial dissolution of the matrix with triisopropanolamine was performed under the conditions previously determined [17]. The treatment was carried out using the general methodology shown below, using a SiO2: diol ratio of $1: 3,3 \%$ in mol of $\mathrm{KOH}$ as catalyst and a 60 minute treatment time.

\section{General Work Methodology [17]}

In a $250 \mathrm{~mL}$ flask, $250 \mathrm{mmol}$ of the diol under study (diethylene glycol or triisopropanolamine) are placed and preheated to $200^{\circ} \mathrm{C}$, at this temperature $5 \mathrm{~g}$ of ore (approximately 83.33 $\mathrm{mmol}$ ) and $7.5 \mathrm{mmol}$ of the base under study are added (3\% mol with respect to diol); once the mineral is added, a distillation system is placed and the mixture is kept under stirring at $220^{\circ} \mathrm{C}$ for $1 \mathrm{~h}$. at the end of time the reaction mixture is cooled and dissolved in $100 \mathrm{~mL}$ of chloroform to recover the unreacted solid by filtration. The solid is washed with 2 portions of $10 \mathrm{~mL}$ of chloroform and 2 portions of $10 \mathrm{~mL}$ of acetone, dried at $90^{\circ} \mathrm{C}$ for $12 \mathrm{~h}$ and calcined at $700^{\circ} \mathrm{C}$ for $1 \mathrm{~h}$ to determine the percentage of unreacted ore.

\section{Effect of the type of base on the dissolution of the silica matrix}

The effect of the type of base on the dissolution of the matrix was evaluated using the following organic and inorganic bases (Table 1), according to the general methodology already mentioned above.

\begin{tabular}{|c|c|}
\hline Organic Bases & Inorganic Bases \\
\hline Ethylenediamine $\left(\mathrm{H}_{2} \mathrm{NCH}_{2} \mathrm{CH}_{2} \mathrm{NH}_{2}\right)$ & $\mathrm{KOH}$ \\
\hline Ethylenamine $\left(\mathrm{CH}_{3} \mathrm{CH}_{2} \mathrm{NH} 2\right)$ & $\mathrm{NaOH}$ \\
\hline Diethyleneamine $\left(\left(\mathrm{CH}_{3} \mathrm{CH}_{2}\right)_{2} \mathrm{NH}\right)$ & \\
\hline Triethyleneamine $\left(\left(\mathrm{CH}_{3} \mathrm{CH}_{2}\right)_{3} \mathrm{~N}\right)$ & \\
\hline
\end{tabular}

Table 1 Type of bases evaluated in the dissolution of the matrix 


\section{Results}

Table 2 summarizes the mineralogical characterization of the mineral under study, observing the presence of silver in the form of sulphides and chlorides, encapsulated in quartz with sizes ranging from $100 \mathrm{~nm}$.

\begin{tabular}{|c|c|c|c|}
\hline & \multicolumn{2}{|c|}{ Mineralogical Composition } & Bargain \\
\hline Ag & $\begin{array}{l}\text { Querargirita }(\mathrm{AgCl}) \\
\text { Acantita }(\mathrm{Ag} 2 \mathrm{~S}) \\
\text { Freibergite } \\
(\mathrm{Ag} 6 \mathrm{Cu} 4 \mathrm{Fe} 2 \mathrm{Sb} 4 \mathrm{~S} 13)\end{array}$ & $<1 \mu \mathrm{m}$ & \multirow[t]{3}{*}{$\begin{array}{l}\text { SiO2 quartz }[58 \square \mathrm{m}] \\
\text { Aluminum Silicates of } \mathrm{Ca}, \mathrm{Mg} \text {, } \\
\mathrm{K} \text { (anortite, sanidine) }\end{array}$} \\
\hline Mn & \multicolumn{2}{|c|}{ Psilomelan [(Ba, H2O) Mn5O10] } & \\
\hline $\mathrm{Fe}, \mathrm{Ti}$ & \multicolumn{2}{|c|}{$\begin{array}{l}\text { Iron Oxide }(\mathrm{Fe} 2 \mathrm{O} 3) \\
\text { Ilmenite }(\mathrm{FeTiO} 3) \\
\text { Chalcopyrite }(\mathrm{CuFeS} 2)\end{array}$} & \\
\hline
\end{tabular}

Table 2 Mineralogical composition of Jal from Pinos Altos, Cahuisori Chihuahua

The effect of the type of base on the dissolution of the matrix was evaluated with strong inorganic bases and various amines such as diethylamine, triethylamine, n-butylamine and diethanolamine. Figure 1 shows the percentage of dissolution of the matrix with respect to the bases studied, where a dissolution between $20-25 \%$ of the matrix with the inorganic bases can be observed, favoring the dissolution of the matrix with increasing character metal base. In the case of inorganic bases, the dissolution of the matrix is disadvantaged with the increase in the basic character of the amines, with the lower dissolution being observed with ethylenediamine, which is the most basic amine (highest $\mathrm{pKa}, 10.98$ ). Thus, the highest matrix solution was observed with triethylamine with $20.13 \%$.

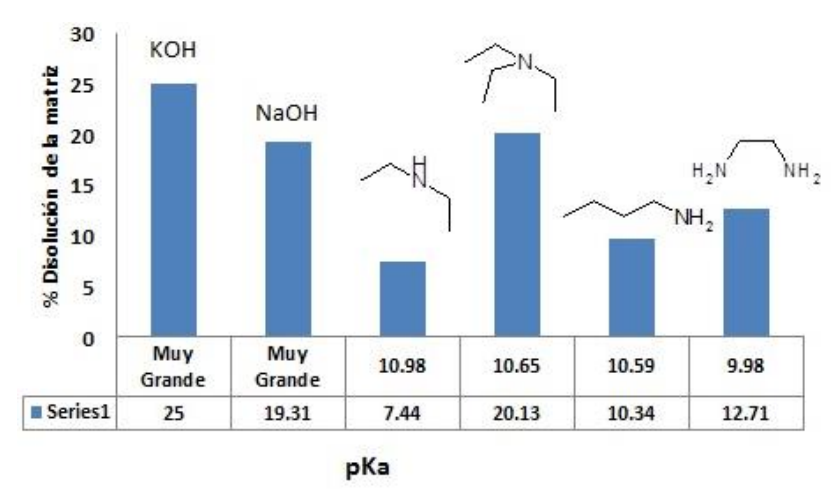

Figure 1 Effect of base type on matrix dissolution

The composition of the matrix after treatment with the various bases under study is summarized in Table 3, where only the detection of silver in the sample can be observed after treatment with tri-isopropanolamine with $\mathrm{KOH}$ and ethylenediamine, this in view of the loss of mass of the matrix in 25 and 13\%, respectively, which allows the pre-concentration of the metal and favors its detection in the sample.
In contrast, the gold composition is reduced by 31 and $6 \%$ for treatment with $\mathrm{KOH}$ and ethylenediamine, respectively. The extraction of this metal may be due to its affinity for donor amino groups.

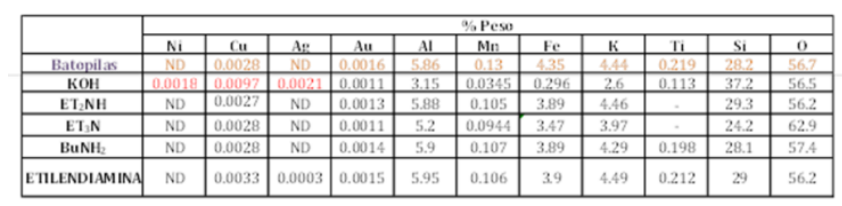

Table 3 Effect of the base type on the extraction of Fe, Mn from the matrix

Figure 2 shows the extraction of Al, Mn, $\mathrm{Fe}, \mathrm{K}$ and $\mathrm{Ti}$ from the matrix with the various bases under study. This Figure shows the dissolution of the aluminosilicate, Fe, Mn and Ti phases of the matrix with the $\mathrm{KOH}$ base. Organic bases, such as: $\mathrm{Et}_{2} \mathrm{NH}_{2}, \mathrm{BuNH}_{2}$ and ethylenediamine, show a zero dissolution of the matrix aluminum, which leads to the nondissolution of the aluminosilicate phases present in the matrix (anortite and sandin), which restricts the dissolution, basically, to the metal oxides of $\mathrm{Ti}, \mathrm{Fe}$ and $\mathrm{Mn}$ present in it. These amines, mainly butylamine, show solvent action of the $\mathrm{K}$ present in the matrix, suggesting that it is present in the mineral sandin (aluminum potassium silicate), and properly as potassium silicate that was not detected in the ore's DRX, this because of the similarity of the signals.

Triethylamine was the organic base that showed the highest dissolution of the matrix, with $20 \%$. This base, unlike the other amines studied, favors the dissolution of the aluminosilicate and silicate phases present in the matrix; as well as the phases of Fe, Mn and Ti present (Figure 2).

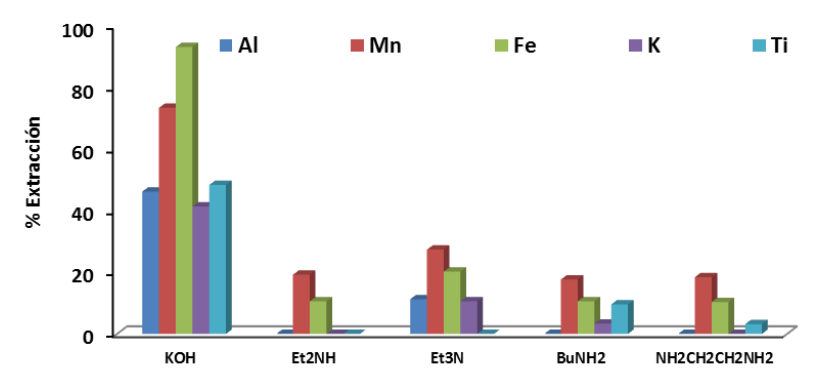

Figure 2 Effect of the type of base on the dissolution of the various metal components of the matrix with triisopropanolamine 
Figure 3 shows the comparative kinetics of the dissolution of the mineral matrix with triisopropanolamine, catalyzed by $\mathrm{KOH}$ and $\mathrm{Et} 3 \mathrm{~N}$, both bases show a balance of dissolution from 60 min and a consumption rate of 1.66 and 0.67 mmolmin-1 for the solution catalyzed by $\mathrm{KOH}$ and Et $3 \mathrm{~N}$, respectively.

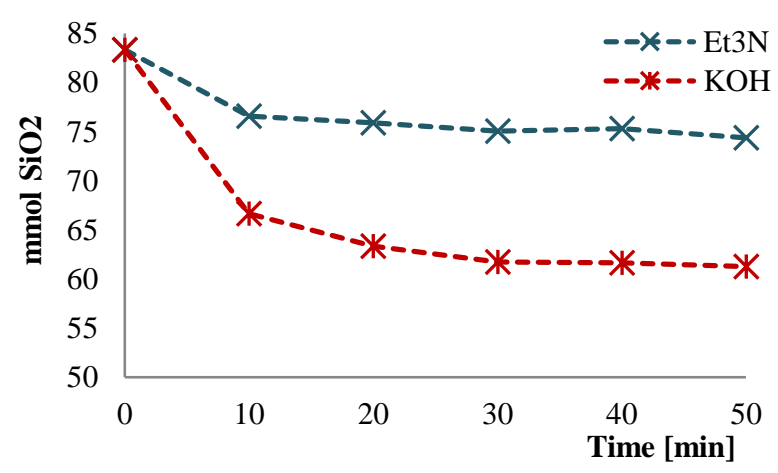

Figure 3 Kinetics of Dissolution of the matrix with triisopropanolamine catalyzed with $\mathrm{KOH}$ and Et3N

The adjustment of the kinetic data to the diffusion case through the ash layer of the decreasing core model (Equation 4.1, Figure 4), showed a magnitude of the effective diffusion coefficient (De) of $4.11 \times 10^{-7} \mathrm{~cm}^{2} \mathrm{~min}^{-1}$ for the reaction catalyzed by $\mathrm{KOH}$, and of $5.11 \times 10^{-8}$ $\mathrm{cm}^{2} \mathrm{~min}^{-1}$ for the reaction catalyzed by the $\mathrm{Et}_{3} \mathrm{~N}$; both reactions show low diffusion coefficients, caused by the passivation of the surface with the diol. It should be mentioned that the curvature observed in the model is due to the lack of incorporation of the particle size distribution to it.

$$
\frac{\mathrm{t}}{\tau}=1-3\left(1-\mathrm{X}_{\mathrm{B}}\right)^{2 / 3}+2\left(1-\mathrm{X}_{\mathrm{B}}\right) \quad \text { Equation } 4.1
$$$$
\tau=\frac{\rho_{\mathrm{B}} \mathrm{R}_{\mathrm{o}}^{2}}{6 \mathrm{bD_{ \textrm {e } } \mathrm { C } _ { \mathrm { A } }}}
$$

\section{Where:}

$\mathrm{X}_{\mathrm{B}}=$ solid mole fraction, dimensionless.

$\tau=$ time limit for the solid to be consumed, minutes.

$\rho_{\mathrm{B}}=$ solid mole density, $\mathrm{mol} / \mathrm{cm}^{3}$.

$\mathrm{R}_{\mathrm{o}}=$ particle radius, centimeters $(\mathrm{cm})$.

$\mathrm{b}=$ stoichiometric coefficient of the solid, according to the dissolution reaction.

$\mathrm{D}_{\mathrm{e}}=$ effective intraparticular diffusion coefficient, $\mathrm{cm}^{2} \mathrm{~min}^{-1}$.

$\mathrm{C}_{\mathrm{A}}=$ concentration of the solvating reagent, $\mathrm{molcm}^{-3}$.

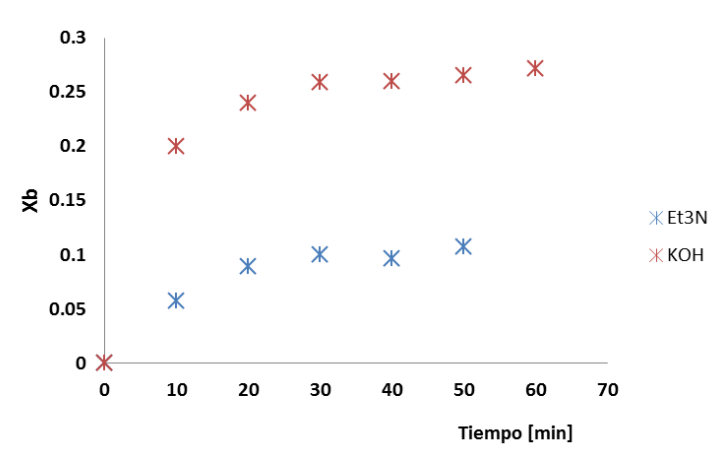

a)

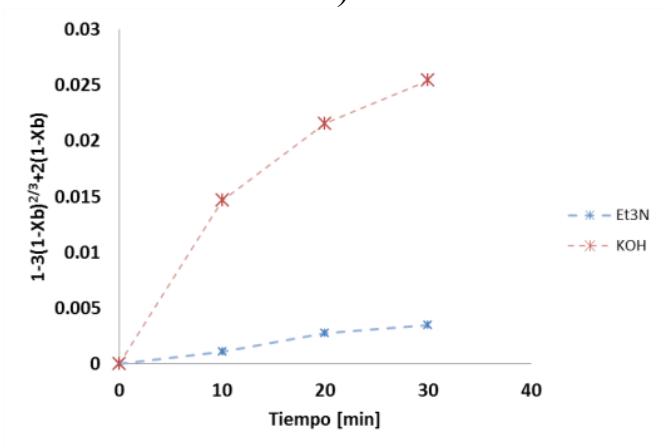

b)

Figure 4 Adjustment of the kinetic data to the kinetic model of increasing nucleus limited by diffusion through the ash layer for Dissolution of the matrix with the triisopropanolamine catalyzed with $\mathrm{KOH}$ and $\mathrm{Et}_{3} \mathrm{~N}$; (a) Kinetic data and (b) Fit to model

\section{Conclusions}

The dissolution of the matrix can be catalyzed by inorganic and organic bases, this work evaluated the catalytic effect of amines such as ethylenamine, triethylene amine, butylamine and diethanolamine. The dissolution of the matrix with these amines occurs in a range of $20-7 \%$ of the matrix, allowing the dissolution of the $\mathrm{Fe}$ and $\mathrm{Mn}$ phases, mainly. $\mathrm{Et}_{3} \mathrm{~N}$ and diethanolamine are the organic bases that allow the dissolution of silica phases such as potassium silicate.

The kinetics of the reaction is limited by the passivation of the surface by the diol, the experimental data were adjusted to the diffusion limit case through the ash layer of the decreasing core model, showing a diffusion coefficient of $4.11 \times 10^{-7}$ and $5.11 \times 10^{-8} \mathrm{~cm}^{2} \mathrm{~min}^{-1}$ for the reaction catalyzed by $\mathrm{KOH}$ and $\mathrm{Et}_{3} \mathrm{~N}$, respectively.

\section{Acknowledgments}

The authors of this work wish to thank the financial support of the SEP-CONACyT through the project CB-2015-257100. 


\section{References}

[1].-Deventer, J. S., Teague. A. J., Swaminathan C. "Factors Affecting the Flotation of free gold in the presence of Refractary Gold" Proceedings of the XXI International Mineral Processing Congress, B8a: 24-32 (2000).

[2].-Aksoy, B. S. and B. Yarar. "Processing of Complex Ores", Pergamon Press, N.Y, (1989).

[3].-Yarar, B. and G. Pine. "Precious metal content of Arizona cinder cones" Elsevier, Amsterdam, (1989).

[4].-Habashi, F. "Kinetics and Mechanism of Gold and Silver Dissolution in Cyanide Solutions". Montana, Departament pf Metallurgy, Montana College of Mineral Science and Technology, pág.: 42,(1967).

[5].-Habashi F. "Kinetics of Metallurgical" Laval University Bookstore, (1999).

[6].-Fink, C. K. and G. L. Putman. "The Action of Sulphide Ion and of Metals Salts on the Dissoltion of Gold in Cyanide Solutions". Mining Engineering Transactions, 187, pág.: 952-955 (1950).

[7].- Cathro, K. J. and D. F. A. Koch. "The Dissolution of Gold in Cynide Solutions-An Electrochemical Study" Australasian Inst. Min. Met. Proc. 210, pág.: 111-126, (1964).

[8].- Cheng H., Tamaki R., Laine R. M., Babonneau F., Chujo Y., Treadwell D. R. "Neutral Alkoxysilanes from Silica" J. Am. Chem. Soc. 122, pág.: 10063-10072, (2000)

[9].- Blohowiak K. Y., Treadwell D. R., Mueller B. L., Hoppe M. L., Jouppi S., Kansal P.,Chew K. W., Scotto C. L. S., Babonneau F. " $\mathrm{SiO}_{2}$ as a Starting Material for the Synthesis of Pentacoordinate Silicon Complexes. 1" Chem. Mater, 6(11), pág.: 2177-2192, (1994)

[10].- Laine R. M., Blohowiak K. Y., Robinson T. R. Hoppe M. L. Nardi P., Kampf J., Uhm J. "Synthesis of pentacoordinate silicon complexes from $\mathrm{SiO}_{2}$ " Nature 353, pág.: 642 - 644, (1991)
[11].- Ma. del Carmen Salazar Hernández. "Estudio de la producción de alcóxidos de silicio a partir de sílice", Tesis de licenciatura (Ingeniero Químico). Universidad de Guanajuato, México. Director de tesis J. A. Gutiérrez, (2003)

[12].- Ma. Mercedes Salazar Hernández "Estudio de la Formación y Reactividad de Alcóxidos de Silicio Obtenidos a Partir de Súlica Gel" Tesis de Doctorado en Química (Química Inorgánica). Universidad de Guanajuato, México. Director de tesis J. A. Gutiérrez, (2009).

[13].- Ma. Mercedes Salazar-Hernández; Marco Antonio Leyva-Ramírez; J. Alfredo Gutiérrez. "Neutral alkoxysilanes from silica gel and $\mathrm{N}$ phenyldiethanolamine" Polyhedron 28, pág.: 4044-4050 (2009).

[14].- Jitchum V., Chivin S., Wongkasemjit S., Ishida H. "Synthesis of spirosilicates directly from silica and ethylene glycol/ethylene glycol derivatives" Tetrahedron, 57, pág.: 3997-4003 (2001).

[15]- Kemmitt T., Henderson W. A "New Route to Silicon Alkoxides from Silica" Australian Journal of Chemistry 51(11), pág.: 1031 - 1035 (1998).

[16] Elorza-Rodríguez Enrique, SalazarHernández Carmen, Puy-Alquiza María de Jesús, Salazar-Hernández Mercedes. "Estudio mineralógico de la disolución de la matriz Silícea en minerales con Plata Ocluida en Silica". Revista de Simulación y Laboratorio (2018) 5(14): 12-17.

[17] Mariano Emmanuel Morales Ramírez; "Estudio de la disolución de la matriz sílice con triisopropanolamina en minerales con oro y/o plata ocluida en sílica", Tesis para obtener el grado de Ingeniero Metalúrgico, 2017, DEPARTAMENTO DE INGENIRÍA EN MINAS, METALURGIA Y GEOLOGÍA, DICGTO. 